\title{
KEPEMIMPINAN: USAHA PEMBERDAYAAN PEMIMPIN BARU MENUJU PERTUMBUHAN ORGANISASI BERKELANJUTAN
}

\author{
Thomas Ulun Ismoyo \\ Character Building Development Center, BINUS University \\ Jln. Kemanggisan Ilir III No. 45, Kemanggisan - Palmerah, Jakarta Barat 11480 \\ ulunismoyo@gmail.com
}

\begin{abstract}
"Leadership is the capacity and the willingness to rally men and women to a common purpose. But it also a character which inspires confidence." These are the words uttered by Bernard Montgomery, a British Field Marshal, when asked what leadership meant to him. From his quote, he reveals the importance of the role of a leader in any organization. A leader will direct and at the same time emit confidence to his followers. In life, human beings are the main catalyst for the world's living history. The same applies to any organization. Human is the most important agent that creates, develops and keeps the whole institution running smoothly. However not everyone is capable of leadership. One needs a competent characteristic and various qualifications to execute the role. The organization must first make an effort and sizeable attention to attract such personnel who can make a valuable contribution to the organization. One of the effort may be to establish a leadership development program. With the specific objective of producing more competent leaders, it needs special leader who can guide, influence, and develop people within the organization. Leadership development becomes a serious task for any organization because its fate and future lies on the capability of its new leaders. Leadership development in every organization is both personal and communal. Personal because there is an individual effort to progress and improve himself so that he will finally be trusted to lead in the organization. However this personal progression needs a support system and a structure that supports and facilitate every type of personality to become a dependable leader. This macro support system is communal in characteristic.
\end{abstract}

Keywords: leadership, leader empowerment, leadership development, continuous organization

\begin{abstract}
ABSTRAK
"Kepemimpinan adalah kemampuan serta kemauan untuk menggalang orang mencapai sebuah tujuan, namun kepemimpinan juga adalah sebuah karakter yang membangkitkan keyakinan”, demikian diungkapkan oleh Bernard Montgomery, Jenderal Lapangan Inggris pada sebuah kesempatan ketika ditanya mengenai makna kepemimpinan yang ia praktikkan. Yang terungkap darinya menggambarkan pentingnya peran pemimpin dalam sebuah organisasi yang berisikan orang-orang yang secara bersama-sama memiliki tujuan tertentu. Pemimpin mengarahkan tujuan sekaligus memberikan keyakinan pada orang-orang yang dipimpinnya.Diakui bahwa manusia adalah aktor utama penggerak sejarah hidup di dunia. Demikian juga dalam sebuah organisasi, manusia adalah pokok terpenting yang mencipta, mengembangkan sekaligus menjaga arah roda organisasi terus berjalan dengan baik. Namun bukan hanya manusia yang apa adanya yang dibutuhkan, melainkan manusia yang kompeten dan memiliki berbagai kualifikasi untuk hal tersebut. Untuk mendapatkan manusiamanusia yang memiliki kontribusi besar bagi organisasi, dibutuhkan adanya usaha dan perhatian yang besar dari organisasi. Salah satu cakupan dari usaha tersebut hadir dalam tema pengembangan kepemimpinan. Dalam rangka mengarahkan diri pada tujuan tersebut, dibutuhkan adanya pemimpin-pemimpin yang bisa mengarahkan, memengaruhi, dan mengembangkan orang-orang di dalam organisasi.Pengembangan kepemimpinan menjadi sebuah karya serius bagi sebuah organisasi, karena dengan dihasilkannya atau tidak dihasilkannya para pemimpin yang cakap, maka proses keberlangsungan organisasi menjadi sebuah pertaruhan. Pengembangan kepemimpinan dalam setiap organisasi bersifat personal sekaligus komunal. Personal dalam arti ada usaha tertentu yang signifikan dari setiap individu untuk maju dan berkembang serta akhirnya dipercayai untuk memimpin kelompok tertentu dalam organisasi. Namun pengembangan personal ini membutuhkan dukungan sistem dan struktur yang mendukung dan memfasilitasi setiap pribadi untuk dapat menjadi pemimpin yang andal. Dukungan dalam skala makro inilah yang disebut bersifat komunal.
\end{abstract}

Kata kunci: kepemimpinan, pemberdayaanpemimpin, pengembangankepemimpinan, organisasiberkelanjutan 


\section{PENDAHULUAN}

Berbicara mengenai pertumbuhan organisasi yang berkelanjutan, maka mau tidak mau harus berbicara mengenai pemberdayaan manusia yang terlibat di dalamnya, yang mengambil bagian dari hal yang paling kecil sampai hal yang paling besar dalam roda organisasi. Berbicara mengenai manusia sudah tentu mengandaikan adanya asumsi tentang kompleksitas dari setiap pribadi manusia yang tidak semata-mata rumit namun juga memperkaya hidup. Sebelum melangkah lebih jauh, tentang manusia itu sendiri, diungkapkan bahwa unsur terpenting yang harus diwujudkan organisasi terhadap manusia adalah pemberdayaan. Istilah ini dapat dipahami sebagai suatu usaha untuk membuat manusia menjadi berdaya, memiliki kekuatan untuk dapat melakukan sesuatu dan lebih jauh lagi untuk mengungkapkan aneka potensi yang ada dalam diri mereka. Dalam konteks organisasi, dapat ditarik benang merah bahwa pemberdayaan manusia adalah aneka usaha yang diterapkan organisasi untuk menjadikan manusia yang terlibat di dalamnya menjadi bernilai lebih, sehingga mereka dapat memiliki kekuatan dan menghasilkan karya sesuai dengan visi dan misi organisasi.

Organisasi bisa memiliki perangkat teknis yang canggih, sarana dan prasarana yang hebat, dan modal investasi dana yang berlimpah, namun tanpa pemberdayaan sumber daya manusia, itu semua tidak akan berarti. Tanpa manusia yang kompeten dan memiliki kekuatan untuk mewujudkan tujuan dari organisasi, semua elemen kunci dari perusahan menjadi tak berarti, bagaikan macan ompong yang tidak akan bertahan hidup lama di hutan belantara.Untuk menjaga dan mengembangkan sumber daya manusia dalam organisasi, dibutuhkan suatu kepemimpinan sebagai kompetensi yang wajib dimiliki oleh orang-orang yang memegang posisi kunci dalam perusahaan. Atau dengan kata lain, memiliki banyak bawahan yang ia pimpin. Tanpa pemimpin yang andal, yang dapat memengaruhi dan membawa anak buahnya untuk mencapai tujuan tertentu dari sebuah organisasi, niscaya pemberdayaan manusia tidak akan berjalan dengan baik. Konsekuensi lanjutan yang dapat terjadi adalah organisasi tidak akan dapat berkembang dengan baik.

Tulisan ini akan dibagi menjadi tiga bagian. Pada bagian pertama yaitu pendahuluan, dimuat mengenai latar belakang yang menjadi alasan untuk mengangkat ide kepemimpinan sebagai tema tulisan. Selain itu, pada bagian identifikasi masalah ada pengerucutan tentang hal yang akan dibahas mengenai kepemimpinan. Pada bagian kedua, sebagai bagian inti dari tulisan ini, penulis membaginya dalam dua subbagian. Pada subbagian pertama, akan ditelaah lebih jauh mengenai aspek-aspek kepemimpinan sebagai sebuah usaha untuk mengembangkan, memberdayakan, dan menjadikan orang lain sebagai pemimpin yang meneruskan karya organisasi. Sedangkan pada subbagian kedua, akan diuraikan mengenai peran organisasi dalam menciptakan pengembangan kepemimpinan. Sementara itu, pada bagian ketiga akan disimpulkan pokok yang menjadi kesimpulan dari studi ini sekaligus menjadi jawaban atas identifikasi masalah, serta diuraikan sejumlah saran terhadapnya. Bagian penutup menjadi semacam evaluasi akhir dan refleksi terhadap artikel ini.

Dilatarbelakangi oleh kenyataan yang telah diuraikan, tulisan ini mencoba untuk mengupas tema tentang kepemimpinan yang memberdayakan seluruh elemen organisasi sehingga dapat menghasilkan pertumbuhan yang berkelanjutan. Maka dari itu, ada tiga hal yang ingin dijawab dalam tulisan ini. Pertama, bagaimana memahami istilah kepemimpinan sebagai sebuah pemberdayaan manusia? Kedua, bagaimana caranya agar hal tersebut dapat diwujudkan dalam sebuah organisasi? Ketiga, apa values dan efforts dari perusahaan yang diperlukan agar hal tersebut dapat diwujudkan dan bagaimana strategic direction yang bisa diusahakan oleh organisasi? 


\section{METODE PENELITIAN}

Untuk mengulas lebih jauh tentang tema kepemimpinan sebagai sebuah pemberdayaan demi keberlangsungan organisasi, penulis menggunakan metode penelitian pustaka dari berbagai sumber yang relevan. Sumber tersebut terutama berasal dari success story Stanley Atmadja, CEO PT. Adira Finance. Untuk memperkuat metode pustaka ini, penulis juga mewawancarai Bapak Joseph Bataona, mantan HR Director PT. Unilever Indonesia.

\section{HASIL DAN PEMBAHASAN}

\section{Kepemimpinan: Memengaruhi, Mengembangkan, dan Memberdayakan}

Pengembangan kepemimpinan dalam sebuah organisasi merupakan kerjasama yang berlangsung dua arah, dari si pekerja itu sendiri dan dari perusahaan atau dari segi mikro (personal) dan dari segi makro (sistem komunal). Beberapa hal pengembangan kepemimpinan yang berlangsung dalam skala mikro, akan diuraikan sebagai berikut.

\section{Memengaruhi dan Mengembangkan}

Mencermati istilah "kepemimpinan” maka akan ditemukan aneka kemajemukan definisi, termasuk dalam cakupan tentang organisasi.Yukl(2004)mengemukakan bahwa dari ragamnya, definisitentang "kepemimpinan" tetap ditemukan sejumlah unsur yang sama,yaitu adanya sebuah prosesmemengaruhi dari satu orang (pihak) pada orang (pihak) lainnya sehingga pihak lain itu mampubertindak sesuai dengan arah dan tujuan organisasi. Kepemimpinan pertama-tama adalah sebuah "seni" memengaruhi pihak lain untuk bertindak.

Teori di atas bukanlahsemudah membalikkan telapak tangan.Ada kompleksitas dan kerumitan dalam sebuah proses panjang sehingga kompetensi kepemimpinan dapat diraih. Pertama-tamakita harus membedakan terlebih dahulu tentang kata "memengaruhi" yang diperlawankan dengan kata "menyuruh". Walaupun keduanya menghasilkan dampak yang sama, yaitu bahwa orang lain berbuat sebagaimana yang diminta, tindakan "memengaruhi" tidak sama dengan tindakan "menyuruh" bawahan untuk melakukan sesuatu. "Menyuruh" senantiasa berkonotasi negatifkarena bawahan berada sebagai pihak yang ditekan, di bawah ancaman dari atasannya. Motivasi yang menggerakkan adalah rasa takut berhadapan dengan otoritas. Sedangkan di lain pihak, istilah "memengaruhi" lebih berkonotasi positif. Ada asosiasi kebebasan dan otonomi manusia dalam melakukan sesuatu. Ada motivasi batiniah tertentu yang menggerakkan dirinya untuk mau berbuat.

Pertanyaannya sekarang, mengapa mereka (pekerja) mau mengikuti kita, secara bebas alias tidak merasa disuruh dan diperintah? Mengapa mereka bisa dipengaruhi? Mengapa mereka mau berada dalam pengaruh untuk berbuat sesuatu? Jawabannya adalah karena ada nilai-nilai (values) yang juga dikejar oleh pekerja dalam hidupnya. Orang mau ikut untuk berbuat sesuatu, untuk dipengaruhi oleh pemimpinnya alias untuk ikut dengan si pemimpin, karena melihat bahwa dengan tindakannya itu, diri mereka pun berkembang ke arah pencapaian nilai-nilai yang juga dituju. Ada visi dan arah tujuan yang jelas, yang jika mereka memperjuangkannya, maka hidup mereka pun akan mencapai sebuah kepenuhan. Mereka mau ikut karena mereka mendapatkan sesuatu, belajar sesuatu, dan hidupnya pun berkembang.

Maka yang menjadi khas dari seorang pemimpin bukan saja kemampuannya untuk memengaruhi orang lain, tetapi juga sekaligus mengembangkannya. Ia bukan saja sebagai orator atau ahli retorika yang pandai berkata-kata, tetapi harus sekaligus menjadi seorang "creator" alias pencipta 
lahirnya pemimpin-pemimpin lain dari bawahan yang berkembang ke arah tersebut. Sebagaimana diungkapkan oleh Atmadja (2009), bahwa "tugas terbesar seorang pemimpin adalah menjadikan anakanak buahnya sebagai pemimpin penerus yang mumpuni untuk menjaga keberlangsungan organisasi”. Seperti pepatah yang mengatakan "guru kencing berdiri, murid kencing berlari", demikian juga seorang pemimpin harus sampai pada tingkatan untuk dapat membuat bawahan-bawahannya dapat berlari kencang.

\section{Dari Biasa Menjadi Bisa dan Luar Biasa}

Dalam sebuah organisasi, selalu ada jabatan atau posisi berkaitan dengan sumber daya manusia (human resources) yang dewasa ini semakin kental dinyatakan sebagai mitra bisnis (business partner) bagi proses produksi suatu organisasi. Bila dilihat dari etimologi yang digunakan, yaitu "sumber daya manusia”, maka jelaslah sudah bahwa manusia adalah 'sumber kekuatan', 'sumber daya’ yang menggerakkan kehidupan organisasi. Manusiayang memiliki "power” sehingga organisasi bisa tumbuh secara berkelanjutan.

Arus umum yang tampak adalah tentang pentingnya manusia dan pengembangannya dalam sebuah organisasi. Salah satu turunan dari istilah "pengembangan” adalah "pemberdayaan", yaitu orang dibuat berdaya, dibuat memiliki kekuatan (power), dibuat mampu untuk melakukan sesuatu sebagaimana disyaratkan oleh organisasi. Misalnya mereka yang dahulu tidak bisa berbicara di depan umum, kini dibuat bisa. Mereka yang tidak mampu mengeluarkan gagasannya secara logis dan teratur, kini dibuat mampu berpendapat dengan baik. Maka pemberdayaan (empowerment) adalah usaha untuk membuat orang menjadi mampu untuk berbuat sesuatu. Mereka yang tidak bisa menjadi bisa. Mereka yang sudah bisa, kini menjadi ahli. Mereka yang biasa menjadi luar biasa. "They become able, they become expert, they become extraordinary"; itulah intisari dari konsep "pemberdayaan". Akhirnya,orang-orangyang berdaya inilah yang akan menjadi aktor penting dalam roda organisasi. Ada banyak pembahasaan, dari segi manajemen dan juga psikologi tentang bagaimana pemberdayaan itu dilakukan sebagai sebuah proses pelatihan kepemimpinan, seperti misalnya konsep "situational leadership" yang mengedepankan teknik partisipatif dan delegasi dalam organisasi. Menurut Yukl (2004), dalam teknik tersebut para pimpinan melibatkan bawahan untuk mengambil bagian, bahkan mengambil keputusan, dalam sebuah tindakan yang menentukan bagi perkembangan organisasi.

Di sini lagi-lagi terlihat peran pemimpin untuk memberdayakan orang-orang di bawahnya. Pemimpin harus memiliki kompetensi yang mumpuni dalam proyek pemberdayaan. Namun selain bahwa ia harus tahu betul teknik dalam pemberdayaan bawahan, seorang pemimpin juga harus mengenal bawahannya. Ia harus tahu persis siapakah dan bagaimanakah karakter dan kualifikasi orang-orang yang dilibatkan dan diberdayakan untuk sebuah tugas tertentu. Menurut Yukl (2004), pemimpin butuh kompetensi dan koneksi sosial yang kuat terhadap semua orang di bawahnya. Competence and connectedness menjadi sebuah karakteristik yang penting dalam pemberdayaan anak buah untuk menjadi lebih berdaya.

Tanpa kompetensi untuk menerapkan ciri pemberdayaan bagi para bawahan dan tanpa koneksi sosial yang kuat alias relasi yang mantap dengan bawahannya, seorang pemimpin sama saja sedang "berjudi" ketika bermaksud untuk memberdayakan orang lain. Akan tetapi, hasilnya malah tidak sesuai dengan cita-cita dan harapan organisasi. Kompetensi kepemimpinan bisa dilatih dalam berbagai program pengembangan. Namun bagaimanakah melatih koneksi sosial alias keterhubungan dengan anak buah-anak buahnya? Ada banyak cara dan metode dari para pemimpin besar dalam meningkatkan hubungan interpersonal dengan bawahannya. Tindakan-tindakan kecil semisal menanyakan kabar keluarga, memberikan ucapan selamat ulang tahun, dan sejenisnya menjadi salah salah satu sarana untuk menjalin relasi yang lebih baik dengan bawahannya.

Dalam bukunya, Halpern danLubar (2003)menyatakan bahwa keterhubungan (interconnectedness) diperoleh seorang pemimpin ketika ia secara otentik menunjukkan empati pada segenap karyawan, mendengarkan mereka, dan membagikan pengalaman hidupnya pada mereka. 
Keterhubungan dengan para bawahan akan terbentuk ketika seorang pemimpin bersedia bergerak keluar (reaching out) dan mencoba mengenal situasi dan kondisi personal mereka. Berempati dengan situasi hidup bawahan dan mendengarkan mereka tidak berarti bahwa seorang pemimpin harus setuju dengan mereka dan tidak lagi memiliki batas antara pihak yang mengatur dengan pihak yang diatur dalam cakupan kinerja di organisasi. Kedekatan mereka tetap harus membuat pemimpin bersikap otonom dan punya stand point yang jelas. Jika keliru, pemimpin berani untuk mengatakan yang sebenanya, semisal, "kali ini saya tidak sependapat", atau "cobalah kamu melihatnya dari perspektif yang berbeda dan cobalah cari cara lain untuk mengatasinya". Bahkan, seorang pemimpin pun harus tetap jujur secara orisinal bersikap pada pekerja yang tetap frustasi dan tidak menunjukkan peningkatan performa dengan berani mengatakan, "sepertinya di tempat ini kamu tidak berkembang, dan sepertinya kamu harus pergi”.

Tampilnya pemimpin yang memberdayakan, yang memiliki kompetensi dan keterhubungan yang dalam dengan bawahannya dilihat sebagai aspek penting dalam mempertahankan pekerja (retain) untuk tetap berada dalam organisasi. Menurut Halpern dan Lubarn (2003), sebuah hasil studi dari Gallup Organization yang didasarkan pada wawancara dengan satu juta pekerja dan delapan puluh ribu manajer menghasilkan kesimpulan bahwaorang meninggalkan manajer, bukan perusahaan. Maka jika terjadi masalah dengan banyaknya orang yang meninggalkan organisasi (turnover), lihatlah pertama kali pada para manajer.

\section{Let Others Take Off: Jiwa Pokok Kepemimpinan}

Atmadja (2009) mengungkapkan bahwa tugas terberat dari seorang pemimpin adalah menciptakan pemimpin-pemimpin lainnya. Secara teknis, dari aneka pelatihan dan pengembangan, hal tersebut bisa dilakukan. Ada cetak biru dari sejumlah organisasi untuk mengembangkan sebuah kepemimpinan kolektif, yang di dalamnya ada banyak pemimpin yang bisa diciptakan. Namun pertanyaannya sekarang adalah relakah para pemimpin melihat anak buahnya menyamai kemampuan dirinya atau bahkan melebihi dirinya? Harus diakui bahwa manusia kerapkali memiliki kelemahan yaitu tidak ingin disaingi kehebatannya oleh orang lain.

Dalam perbincangan kecil dengan Bapak TH. Wiryawan(Februari 2012) seorang mantan petinggi Citibank, terungkap hal seperti ini: jika di indonesia, seorang atasan bertanya kepada anak buahnya, “Apa yang kau inginkan dalam tiga tahun mendatang?” dan jika anak buahnya menjawab, "saya ingin menduduki jabatan yang sekarang bapak miliki", maka karier anak buah tersebut berada dalam ancaman. Sedangkan bila pertanyaan yang sama diungkapkan dalam perusahaan asing, maka si pimpinan akan membantu si anak buah agar cita-cita dan harapan si anak buah itu dapat tercapai. Terlepas dari jika pendapat ini dapat digeneralisasi pada perbandingan antara perusahaan lokal dengan perusahaan multinasional, kelihatan bahwa pada situasi yang pertama, atasan tidak akan suka dan mulai memikirkan cara agar si anak buahnya itu dapat dimutasi atau di rotasi ke tempat lain. Zona nyaman si pimpinan terganggu karena melihat orang lain menjadi ancaman untuk posisi yang ia miliki. Sedangkan pada situasi yang kedua terlihat bahwa ambisi atau harapan anak buah tersebut menjadi sesuatu hal yang positif bagi pimpinan. Ia bahkan akan mulai memikirkan bagaimana dapat menyediakan kondisi agar cita-cita tersebut dapat terwujud. Ambisi atau keinginan itu bukan dilihat sebagai sesuatu yang buruk melainkan menjadi faktor pendorong untuk kinerja yang lebih baik sehingga membuat organisasi dapat berkembang.

Dari hal ini, bisa dilihat bahwa kepemimpinan adalah mengenai sesuatu yang jauh lebih besar daripada sekadar mengatur dan membuat sesuatu terjadi. Adapun yang jauh lebih besar itu adalah adanya jiwa atau spirit tertentu yang melampaui semua kompetensi teknis yang bisa dilatih. Spirit itu adalah semangat kegembiraan batin ketika melihat orang lain "lepas landas" atau berkembang. Inilah spirit kemurahan hati untuk membuat orang lain menuju kepenuhan hidupnya. Bagaimanapun, lilin (pemimpin) tidak akan redup kalau menerangi orang lain di sekitar kita. 
Maxwell (2011) menulis bahwa kemurahan hati adalah berasal dari dalam hati dan masuk keseluruh aspek kehidupan seorang pemimpin. Inilah jiwa kepemimpinan pokok bagi seorang pemimpin: merelakan dan mendukung orang-orang lain di bawahnya untuk dapat "lepas landas" dan meraih cita-citanya. Jiwa kepemimpinan yang murah hati juga sesuatu yang bisa dilatih, bukan dalam pelatihan profesional melainkan dalam hidup sehari-hari setiap manusia. Di sinilah, ada ruang yang menjadi pintu masuk bagi pengembangan kecerdasan emosional (EQ) dan kecerdasan spiritual (SQ) dalam setiap organisasi. Ada keseimbangan hidup yang diusahakan dan diraih oleh setiap pekerja. Pertanyaannya sekarang, sudahkan setiap organisasi memikirkan atau menyiapkan sarana untuk menjaga keseimbangan hidup bagi para pekerjanya?

\section{Menciptakan Organisasi Pemimpin: Proyek Besar Setiap Organisasi}

Dalam cakupan yang lebih luas, upaya pengembangan kepemimpinan merupakan hal yang harus menjadi keprihatinan utama dari organisasi. Ada cetak biru dari organisasi dalam tema ini sehingga arah dan tujuan organisasi dapat tercapai. Berikut diuraikan gerakan menciptakan kepemimpinan yang diupayakan oleh organisasi.

\section{Arah Strategi Organisasi sebagai Landasan Penciptaan Para Pemimpin}

Organisasi yang kokoh dan tumbuh berkembang secara berkelanjutan selalu didukung oleh para pemimpin yang mumpuni. Berbicara mengenai siapakah pemimpin, tidak menunjuk hanya pada para pemimpin di tingkat jajaran puncak (board of directors), tetapi merangkum pula para pemimpin yang tersebar merata di seluruh tingkatan organisasi. Ada kumpulan pemimpin dalam berbagai jenjang dan level yang bersifat sangat menentukan untuk kemajuan sebuah organisasi.Untuk sampai pada level yang menghasilkan kepemimpinan, ada tahap demi tahap yang harus dijalankan yang berlandaskan pada satu kesamaan visi untuk perkembangan dan pertumbuhan organisasi. Tahap-tahapnya adalah sebagai berikut.

Pertama adalah arah strategi tentang masa depan organisasi. Organisasi membutuhkan arah strategi yang jelas (strategic direction) yang menjadi pedoman untuk bertindak. Arah strategi ini dapat disimpulkan dengan sebuah pertanyaan pokok, “Where are we going?”. Ya, mau dibawa kemana organisasi ini? Arah staregi menjawab pertanyaan tersebut. Didalamnya ditampilkan tujuan jelas yang mengarahkan anggota organisasi untuk bertindak. Strategi ini menjadi semacam guiding principles yang memberi petunjuk, layaknya lentera penerang yang menuntun arah organisasi akan dibawa pada masa depan. Dengannya, seluruh jajaran organisasi, diikat, dan disatukan untuk mewujudkannya.

Salah satu sifat dari arah strategi ini adalah berorientasi jangka panjang, yang dibentuk dari sebuah pemikiran bahwa roda organisasi harus bisa berjalan bukan hanya pada waktu kini melainkan juga pada masa depan. Organisasi yang bertumbuh (sustain) sudah harus memikirkan posisi organisasi lima tahun mendatang atau sepuluh tahun mendatang. Atmadja (2009) mengingatkan bahwa orientasi jangka panjang berarti bahwa anggota organisasi merawat, menjaga, dan mengembangkan (nurturing) organisasi untuk saat ini dan saat mendatang. Sedangkan pada orientasi jangka pendek berarti hanya memanen (harvesting) untuk saat ini saja. Sebagai contoh salah satu contoh arah strategi yang mengedepankan pemberdayaan manusia, bisa dilihat visi sumber daya manusia dari PT. Unilever Indonesia, yang berbunyi “Grow People for Growth". Visi ini sekaligus sebagai arah strategi yang mengedepankan usaha untuk mengembangkan manusia terlebih dahulu, dan dengan manusia yang sudah berkembang atau kompeten, maka perkembangan organisasi akan menjadi efek lanjutan dari hal tersebut. Di sini terlihat bahwa pengembangan manusia menjadi titik kunci untuk perkembangan organisasi yang pada akhirnya nanti dapat menghasilkan buah dan keuntungan yang melimpah.

Arah strategi ini juga yang akhirnya menjadi unsur yang menentukan bagi terciptanya pengembangan kepemimpinan dalam organisasi. Lahirnya para pemimpin adalah buah dari kerja keras 
sistem organisasi. Pada akhirnya, para pemimpin pula yang bekerja keras menjaga keberlangsungan organisasi untuk dapat mencapai tujuan. Ini adalah gerakan timbal balik antara sistem organisasi dengan para pemimpin.

Kedua adalah evaluasi tentang situasi organisasi. Setelah menetapkan pilihan hati pada arah strategi perusahaan yang menjadi penuntun gerakan organisasi untuk mencapai tujuan masa mendatang, perlu pula dilakukan langkah evaluasi terhadap posisi organisasi sekarang. Tahap yang kedua ini dapat disimpulkan dengan pertanyaan, "where are we now?" Istilah "posisi” menunjuk pada keadaan senyatanya yang dimiliki organisasi, seperti misalnya kuantitas dan kualitas manusia dan juga berbagai aspek lainnya. Pada titik ini pertama-tama penting sekali untuk mendapatkan data yang akurat sebagai sumber informasi tentang keberadaan terkini organisasi. Untuk bidang pengembangan sumber daya manusia misalnya, penting sekali pendataan tentang kualifikasi para anggota, baik dari segi potensi, catatan kinerja, dan juga aneka pelatihan yang sudah diikuti. Data mentah ini menjadi salah satu sumber untuk mengkaji dan merencanakan hal-hal yang dapat dilakukan oleh organisasi untuk mencapai sasarannya. Nilai kejujuran menjadi sebuah keutamaan yang signifikan dalam proses evalusi posisi organisasi ini. Menjadi jujur dengan keadaan akan memudahkan langkah selanjutnya dalam menentukan tindakan dan rencana yang harus diambil. Selain itu, kejujuran memudahkan dalam memperkirakan besar investasi yang wajib dianggarkan oleh organisasi untuk mencapai tujuan yang sudah diamanatkan pada arah strategi organisasi.

Setelah menentukan arah organisasidan melakukan evaluasi dini mengenaiposisi organisasi sekarang, yang ketiga adalah menentukan strategi tentang langkah-langkah vital yang harus dilakukan agar tujuan organisasidapat tercapai. Tahap ini dapat dirumuskan dengan pertanyaan "What to do?"; hal yang harus dilakukan oleh organisasi. Tahap ini melahirkan rencana-rencana strategis dari organisasi, yang dapat dirumuskan dengan pertanyaan "How will we get there?" Termasuk di dalam rencana strategis ini adalah rencana menciptakan organisasi yang melahirkan pemimpin. Membuat organisasi sebagai sebuah "pabrik" para pemimpin merupakan sebuah usaha untuk menciptakan kepemimpinan kolektif. Maksudnya adalah para pemimpin hadir di semua elemen dan level dari organisasi.

Terdapat sejumlah hal yang dapat diupayakan oleh organisasi untuk mendukung arah strategi yang berkaitan dengan pengembangan sumber daya manusia demi menghasilkan kepemimpinan yang kolektif. Beberapa contohdi antaranya adalah sebagai berikut. Pertama, menciptakan sarana pelatihan pengembangan kepemimpinan. Pekerja terus menerus mendapatkan kesempatan untuk mengasah dirinya menjadi lebih berkembang; dan organisasi mendukung arah tersebut dengan menyediakan aneka pelatihan. Pekerja yang kompeten dan berkembang tentu akhirnya menjadi lebih kontributif untuk organisasi. Kedua, memberikan fasilitas pengembangan hidup yang seimbang bagi para anggota atau pekerja. Para pekerja juga perlu dikondisikan untuk mencapai pemenuhan hidupnya secara seimbang. Mereka hidup bukan hanya di kantor dan bekerja untuk mencapai target perusahaan, tetapi juga hidup dalam aneka aspek. Mereka punya keluarga, mereka punya hobi, mereka juga butuh sarana rekreasi dan olahraga. Memang tanggung jawab organisasi tidak sampai sangat mendetail pada kehidupan pribadi seorang pekerja, namun sebisa mungkin, organisasi menciptakan kondisi dan situasi yang membuat para pekerja terpenuhi aspek-aspek kehidupan lainnya.

Sebagai contoh, PT Unilever Indonesia dalam salah satu ruangan kantornya disediakan ruang bermain dan juga ruang menyusui untuk anak-anak pekerja yang orang tuanya bekerja di tempat itu. Ini adalah sebuah terobosan inovasi yang patut mendapat apresiasi, karena secara positif telah mengondisikan para pekerja untuk tetap fokus bekerja sambil tetap percaya bahwa orang-orang yang dicintainya mendapat perhatian yang cukup. Contoh lain misalnya, adanya subseksi pembinaan rohani di sebuah perusahaan yang mengoordinasi semua pekerja beragama tertentu untuk mengadakan pembinaan iman secara rutin. Dengan hal ini, diharapkan bahwa kebutuhan spiritual para pekerja pun dapat dipenuhii. Masih banyak contoh lain yang menunjukkan kepedulian organisasi untuk pengembangan hidup pekerja secara holistik. 


\section{Sarana Pelatihan Membangun Talenta Kepemimpinan dalam Organisasi}

Satu yang harus disepakati bersama tentang kepemimpinan adalah bahwa kompetensi atau praktik atau jiwa kepemimpinan bukanlah sesuatu yang turun dari langit. Kepemimpinan tidaklah bersifat genetis hasil warisan dari leluhur. Kepemimpinan bukanlah "hadiah" atau bakat alamiah. Sebagaimana sering didengungkan bahwa kesuksesan adalah sembilan puluh sembilan persen hasil usaha dan hanya satu persen adalah bakat, demikian juga dengan kepemimpinan. Untuk mendapatkan kompetensi kepemimpinan yang andal, dibutuhkan usaha dan proses berkelanjutan.

Usaha dan proses berkelanjutan ini bukanlah bersifat personal, tetapi hadir dalam sebuah sistem atau dilakukan secara makro, menjadi sebuah kebijakan dari hulu ke hilir dari sebuah organisasi. Memang tidak bisa dipungkiri bahwa ada sejumlah tokoh karismatis yang dengan katakatanya saja, orang bisa digerakkan ataupun terinspirasi untuk melakukan sesuatu sebagaimana dianjurkan. Namun tidak bisa dilupakan bahwa ada faktoreksternal yang sangat vital dalam menentukan terbentuk atau tidaknya kompetensi kepemimpinan bagi manusia yang terlibat dalam organisasi tersebut. Faktor-faktor eksternal dalam skala makro, atau yang berasal dari organisasi, yang bisa mendukung lahirnya pemimpin salah satu di antaranya adalah adanya pelatihan yang terprogram, terencana, terlaksana, dan terevaluasi dalam tema kepemimpinan.

Program pengembangan kepemimpinan ini juga merangkum semua pekerja, dari tingkat paling bawah sampai paling atas dengan perbedaan penekanan dan fokus yang ingin dicapai. Berikut dipaparkan tahap-tahap pelatihan pengembangan kepemimpinan yang bisa diusahakan dalam organisasi dalam kerangka menghasilkan para pemimpin yang andal pada setiap levelnya.

\section{Personal Leaderhip}

Ini merupakan pelatihan tahap paling awal yang diberikan kepada pekerja demi memenuhi kompetensi dasar seorang pemimpin. Pada tahap ini target yang hendak dicapai adalah agar pekerja memiliki kemampuan untuk memimpin dirinya sendiri, sehingga ia berkembang dan memiliki kualitas tertentu yang berperan dalam pengembangan organisasi. Kemampuan memimpin diri sendiri adalah modal awal untuk dapat memimpin orang lain dan pada akhirnya nanti juga mempimpin organisasi.

Kompetensi yang dicapai dalam pelatihan ini, misalnya adalah sikap kesadaran diri (self awareness) yang matang dan sikap dapat dipercaya (trustworthiness). Dengan adanya kompetensi kesadaran diri, pertama-tama diharapkan lahir sikap sadar terhadap kemampuan nyata yang ia miliki dengan segala potensi, kekuatan, dan juga aneka kelemahan dirinya. Selain itu digodok pula sikap untuk memiliki kepercayaan diri sendiri. Ia tidak minder dengan keadaan dirinya, melainkan mau belajar dan mau mengemban tanggung jawab. Sedangkan dengan kompetensi dapat dipercaya (trustworthiness), para pekerja menjadi sosok yang memiliki kedewasaan dalam bersikap dan bertindak serta memiliki integritas dalam karyanya di organisasi.

\section{Team Leadership}

Setelah orang diajak untuk mampu memimpin dirinya sendiri, maka pada tahap kedua ini kompetensi kepemimpinan diarahkan pada cakupan yang lebih luas, yaitu kepemimpinan dalam tim. Ia kini harus belajar memimpin orang lain. Ada nuansa sosial untuk mulai memimpin dan mengembangkan orang lain. Ketika cakupannya sudah meluas pada orang lain, maka penting sekali untuk menyelaraskan strategi tim dengan arah dan tujuan organisasi.

Dalam tahap ini bentuk kompetensi yang dilatih adalah tentang memotivasi orang lain dan menumbuhkan empati pada orang lain. Dengan adanya kemampuan motivasi yang andal, seorang pemimpin tim dapat menjadi energi penggerak bagi anggota-anggotanya yang sedang berorientasi 
pada tujuan tertentu. Sedangkan dengan kemampuan berempati, pemimpin tim dapat mengenal anak buahnya, me-monitoring karya mereka, dan akhirnya menumbuhkan sikap terhubung dengan seluruh anggota tim (interconnectedness).

\section{Business Leadership}

Sesudah orang sukses atau teruji dalam memimpin tim, maka tahap pengembangan kepemimpinan berkembang ke arah yang lebih luas dan lebih besar lagi, yaitu kepemimpinan dalam bisnis organisasi. Cakupan orang yang ia pimpin bukan lagi dalam lingkup kecil, melainkan dalam lingkup yang sangat luas, yaitu organisasi itu sendiri. Makin luas cakupan yang dipimpin, makin besar pula tanggung jawab yang diemban untuk memimpin organisasi dan memastikan keberhasilan dan keberlangsungan hidup organisasi tersebut.

Dengan demikian, kompetensi yang dikembangkan dalam pelatihan tahap ini adalah kemampuan membentuk visi dan pelatihan keterampilan sosial (social skills). Dalam kompetensi membentuk visi, peserta pelatihan diajak untuk dapat menetapkan fokus organisasi, menatap masa depan keberlangsungan organisasi, dan merangkai strategi yang diperlukan. Sedangkan dalam kompetensi social skills, peserta pelatihan diharapkan memiliki kemampuan untuk menciptakan jaringan (create network), mengatur tim-tim di bawahnya (manage teams), dan juga menjaga relasi yang baik dalam organisasi (manage relationship).

Bentuk-bentuk pelatihan ini haruslah bervariasi dan memperhitungkan yang didapat dalam setiap model pelatihan yang dipraktikkan. Sebagai pengingat, prinsip bentuk pelatihan adalah sepuluh banding dua puluh banding tujuh puluh persen (10:20:70). Sepuluh persen dari pelatihan ditempuh dengan cara tradisional, semisal workshop, seminar, atau kursus singkat. Dua puluh persen kemudian diperoleh dari proses sosial semisal diskusi, coaching, on the job training, dan mentoring. Sedangkan tujuh puluh persen sisanya diperoleh dari adanya pemberian tugas tertentu (assignment) yang menghasilkan pengalaman kerja tertentu. Dengan adanya tugas, seorang peserta pelatihan kepemimpinan ditantang untuk mengaktualisasikan dan mempraktikkan ilmu yang didapat dalam sebuah karya nyata. Keterlibatan secara total dalam tugas inimenjadi faktor penting dalam keberhasilan proses pelatihan.

Proses panjang dalam pelatihan demi pelatihan sebagaimana yang disebutkan menjadi penanda bahwa organisasi tersebut memiliki model atau skema penciptaan pemimpin-pemimpin yang cakap dalam organisasi. Menurut Atmadja (2009), skema ini mencakup dua hal, yaitu melakukan proses seleksi calon pemimpin (leader selection) dan mengupas proses penciptaan-pengembangan pemimpin (leader development). Dalam tahap demi tahap pelatihan tersebut, selain ada proses peningkatan pelatihan kepemimpinan, dari memimpin diri sendiri sampai memimpin organisasi, termuat juga proses seleksi tentang kandidat yang berhak untuk mengikuti tahap selanjutnya dari pelatihan kepemimpinan. Lebih lanjut menurut Atmadja (2009), proses evaluasi menjadi penting dalam setiap pelatihan untuk melihat sejauh mana kompetensi-kompetensi kepemimpinan tersebut sudah dimiliki oleh pekerja dan bernilai bagi organisasi serta dalam rangka seleksi kandidat yang memiliki kesempatan lebih besar dan lebih cepat untuk maju menjadi pemimpin.

\section{SIMPULAN}

Mencermati yang sudah diuraikan dalam pembahasan, ada sejumlah kesimpulan dan saran yang bisa diajukan, sebagai berikut. Pertama, isu tentang kepemimpinan pertama-tama merupakan sebuah proses memengaruhi orang lain sehingga mereka mengikuti atau melaksanakan yang menjadi cita-cita organisasi. Tidak hanya digerakkan oleh kepentingan bersama, kepemimpinan menunjukkan 
taringnya jika berhasil menciptakan generasi penerus yang memiliki kapasitas dan kompetensi yang sama, bahkan lebih tinggi. Sebagai saran riil, para pemimpin yang ada sekarang diajak untuk memperlengkapi kompetensi yang mereka miliki dengan sebuah spirit pokok kepemimpinan, yaitu melahirkan pemimpin-pemimpin baru.

Kedua, usaha menciptakan pemimpin adalah proyek raksasa yang harus melibatkan seluruh elemen dalam organisasi. Dari sisi pekerja, kepemimpinan merupakan kompetensi yang harus diusahakan dan diraih dalam level dan kepentingan yang berbeda-beda sehingga ia bernilai bagi organisasi. Dari sisi organisasi, munculnya pemimpin-pemimpin baru adalah langkah besar dan strategis untuk dapat mengarahkan setiap anggota organisasi dapat bekerja maksimal. Sebagai saran riil, proyek raksana ini harus memiliki cetak biru perencanaan pengembangan sumber daya manusia (human resources planning) yang disetujui dan didukung oleh organisasi berdasarkan arah strategi yang telah ditetapkan. Maka dari itu, arah strategi dari organisasi mesti dibuat dengan menunjukkan keberpihakan pada pengembangan sumber daya manusia yang akhirnya menghasilkan para pemimpin yang cakap.

Ketiga, kepemimpinan tetaplah sebuah kompetensi yang bisa diusahakan dan diraih dengan segala usaha pembelajaran dan pelatihan. Dengan demikian, organisasi perlu memikirkan secara serius dan mengimplementasikannya secara nyata tentang adanya suatu pelatihan kepemimpinan yang berkelanjutan. Ada target-target kompetensi yang riil dan bisa diraih dan ada pula teknik evaluasi yang kredibel terhadap semua bentuk pelatihan tersebut. Sebagai saran adalah penting bagi organisasi memiliki concern pada ketersediaan pelatihan kepemimpinan tahap demi tahap. Inilah usaha nyata organisasi untuk dapat menghasilkan para pemimpin secara kolektif.

Studi tentang peran kepemimpinan dalam rangka pemberdayaan manusia demi pertumbuhan organisasi yang berkelanjutan telah memberikan pencerahan bagi penulis tentang hal yang perlu diupayakan untuk menciptakan para pemimpin yang cakap dan kompeten dalam sebuah organisasi. Ini semua tidak ditempuh secara instan, melainkan melalui sebuah proses panjang yang melibatkan seluruh elemen organisasi, mulai dari pemimpin perusahaan (director), bidang pengembangan sumber daya manusia (human resources department), para manajer, dan akhirnya para anggota ataupun setiap pekerja. Kompleksitas semakin bertambah karena tema kepemimpinan berurusan dengan yang namanya "manusia" dengan segala aspek kehidupannya: pikiran, hati, jiwa, kebutuhan, relasi sosial, dsb. Mereka bukan mesin yang bekerja secara mekanis, mereka bukan robot yang dapat digerakkan oleh sebuah remote control dengan tombol-tombol tertentu. Mereka adalah manusia.

Ide tentang kepemimpinan adalah ide tentang memimpin dengan segala ragamnya. Memimpin manusia tidak berarti semata-mata memengaruhi mereka untuk dapat mencapai tujuan tertentu. Jika ini yang menjadi pola pikir dari sebuah organisasi, definisi tentang kepemimpinan menjadi sangat miskin. Akan tetapi, memimpin manusia adalah memengaruhi mereka untuk mencapai tujuan organisasi sekaligus mengembangkan mereka menjadi orang-orang yang berpotensi, berkompetensi, dan akhirnya juga dapat memimpin manusia-manusia lainnya.

Karisma seorang pemimpin lahir dari suatu proses yang panjang hasil simbiosis mutualisme atau kerjasama yang saling menguntungkan antara organisasi dengan anggotanya. Organisasi perlu menetapkan arah strategi dasar yang menjadi landasan dari pengembangan kepemimpinan, sehingga berbagai kebijakan dari organisasi terarah pada tujuan atau sekurang-kurangnya mendukung lahirnya para pemimpin yang kompeten dan kontributif bagi organisasi. Para pekerja pun perlu membuka hati dan menyempatkan diri untuk berkembang: memberi waktu untuk belajar, melatih diri, dan akhirnya bisa tampil sebagai pemimpin pada masa mendatang. Kesuksesan atau keberhasilan seorang pemimpin bukan ditentukan oleh keberhasilan organisasi selama ia menjadi pemimpin di tempat tersebut, melainkan bahwa sesudah ia mundur atau tidak lagi menjadi pemimpin di tempat tersebut organisasi masih terus tumbuh dan berkembang, karena ada generasi penerus kepemimpinan yang dapat diandalkan. Pemimpin disebut sukses ketika meninggalkan warisan yang terutama, yaitu lahirnya 
pemimpin-pemimpin baru. Di sini pokok terpenting dimunculkan dalam tema kepemimpinan, yaitu kemurahan hati untuk mengembangkan, membantu, dan mendukung orang lain untuk "mengepakkan sayapnya” dan melesat ke atas.

\section{DAFTAR PUSTAKA}

Adiprasetyo,A.(Selasa, 13 Maret 2012). KEPEMIMPINAN “Kambing Menggonggong?”. Jakarta: Kompas.

Atmadja, S. S.(2009). Making The Giant Leap, How to Unleash The Extra Ordinary Human Potential. Jakarta:Gramedia Pustaka Utama

Halpern, B. L. and Lubar, K. (2003). Leadership Presence. New York:Gotham Books.

Maxwell, J. C. (2011). The 21 Indispensable Qualities of A Leader. terj. Marlene T. Surabaya: MIC Publishing.

Yukl, G. (2004).Leadership in Organizations.New York: Prentice Hall. 